\title{
Legal Comparisons Regarding the Content of Franchise Prospectus in Legal System of United States of America, Australia, Indonesia For Legal Protection of Frait Recipients in Indonesia
}

\author{
Rika Githamala Ginting \\ Faculty of Law, Parahyangan Catholic University, Bandung
}

\begin{abstract}
The prospectus document is given as a consideration for the franchisee whether they want to participate in operating the franchise or not. Apart from being used as a medium to find out information about franchises, this prospectus is also a form of legal protection for franchisees. Article 7 of the Government Regulation on franchising regulates clauses that must be included in the prospectus. The regulations governing minimal clauses in this prospectus are quite minimal. Compared to the United States, which is the originating country for franchising and Australia, which follows the United States in regulating its franchises, Indonesia is still far behind in the preparation of its prospectus documents. The method used is the legal comparative research method because it is used to compare regulations in a country with other countries. The research results show that each prospectus minimum clause in Indonesia has its own objectives in terms of protecting prospective franchisees and franchisees. There are differences between the clauses that must be listed in the prospectus in the United States, Australia and Indonesia, where there are clauses that are regulated in the United States and Australia which are not regulated in the minimum clause of the prospectus in Indonesia, although there are differences, but there are also clauses that are the same regulated in the three countries, it's just that the explanation of the provisions has differences. Regarding whether Indonesia's prospectus is capable of, Indonesia's minimum clause has not been able to provide protection for franchisees in Indonesia.
\end{abstract}

Keywords

Prospectus; legal protection; franchisor; franchisor; franchisee

\section{Introduction}

One of the ways used by entrepreneurs in developing their business is by using the franchise method (franchising). This method of business development with a franchise system can be found in various places and regions, especially in Indonesia. The use of this business is considered to be able to accelerate the development of a business not only domestically but also to expand their business overseas. At this time there have been many businesses selling goods and services that use the franchise system which are not products or businesses of domestic entrepreneurs but from abroad. The products that are marketed are usually food sales services, hotels, mini markets and clothing supply businesses.

The use of the franchise system is in great demand by entrepreneurs because this method is considered capable of accelerating the development of a business by collaborating with other parties and is able to create new jobs for many people. The franchise system is considered to have many advantages, especially regarding funding, 
human resources and management, except for the willingness of brand owners to share with other parties, and franchising itself is also known as a very effective distribution channel to bring products closer to consumers through the hands of the franchisee.

The use of this franchise method is not only used by entrepreneurs to develop their businesses nationally. Many entrepreneurs use this method to develop their business to an international level. A franchisor in developing his business in another country must know with certainty the legal provisions in force in the country where the franchise will be awarded or developed, so that later when the cooperation between the franchisor and the franchisee has ended, the franchisee does not change his form from business partners become competitors for the franchisor. Foreign franchisees are also required to respect the existing norms and apply in Indonesia.

On the other hand, a person or party who is a franchise recipient who carries out business activities as a business partner of the franchisor according to the terms and procedures given, also requires certainty that the business activity that is being carried out by him has actually been tested and is a preferred product. by society, and will be able to provide a benefit (financially) for him. This is very necessary so that the franchisee can feel guaranteed that the franchise business that he will be running or is running is a business that has been tested and proven to bring benefits to him, as well as convincing franchisees to continue to cooperate to develop the business of the franchisor if their cooperation agreement has ended later.

Prior to the agreement between the franchisor and the franchisee, the franchisor will first submit a prospectus document to the prospective franchisee to be used as an initial introduction to the business to be run and as a consideration for potential franchise recipients. Prospectus is a marketing tool as a medium that provides an overview of how the business is being run and provides complete information about the business being offered as well as the rights and obligations of the franchisor.

This prospectus document is one of the most important parts of running a franchise business. This prospectus is not only important for the franchisor who is used as an introduction to his franchise business, but it is also important for franchisees to get important information related to the franchise that will be or are running. The information contained in a franchise prospectus document will later be used by candidates and franchisees as a material for consideration whether the franchise is feasible or not to run, so that the franchisee does not make the wrong choice in running a franchise business.

It is through this prospectus document that prospective franchisees will understand about the business they will run and what benefits and rights they must carry out if they want to take part in running and developing the business. This prospectus document is likened to a bridge to connect the franchisor and franchisee. The prospectus can also be considered as a liaison whether the franchisee is willing or not to run the franchise business that is offered to him to achieve the desired goals. Franchise recipients, if the conditions set are inadequate then it is feared that it will harm the franchisees.

As a developing country, the government can rely on several regulations that exist in various countries in running a franchise business. In some countries, such as the United States and Australia, it can be seen clearly that in this regulation regarding the franchise business, both the franchisor and the franchisee are clearly regulated regarding the obligations and responsibilities of each party.

Clearly the arrangements regarding the limitations and obligations that must be carried out in running this franchise business make the franchisor and franchisee feel safer and more secure in their rights. The openness shown in the existing regulations in both 
countries can convince potential franchise recipients and can also guarantee franchise recipients if they want to run the business, they will be protected from unwanted things.

The United States is a country that has a big share in developing this franchise method. Many of the franchise products originating from the United States are already growing rapidly around the world. The United States is also considered a mecca for entrepreneurs to be able to develop their business through this franchise method. Many countries from around the world are looking to the United States how companies and governments in the United States regulate business with this franchise method, including Indonesia.

The existence of the government is closely related to the function of public service. Progress in the field of technology and information is one of the challenges for the government in providing more effective, efficient and accountable services. The technology advance characterized by technology digitalization requires the government to better deliver quality of service by utilizing all of the resources the government has and improving performance. (Karyono and Agustina, 2019)

Another country that will be the object of comparison in this case is Australia. Australia is a developing country and a country with good economic growth and business development in the world, including in doing business in this form of franchising. The development of franchising in Australia is also quite rapid. Australia has also made the United States a mecca for making franchise regulations in the country.

\section{Review of Literature}

\subsection{The Relationship of the Content of the Prospectus to Legal Protection for Franchisees in Indonesia}

Indonesia, through its regulations, regulates a minimum clause that must be fulfilled and set forth by the franchisor in its prospectus document. The application of the minimum clause in this prospectus is intended so that franchisors do not only include things that will benefit themselves. The application of the contents of this prospectus is regulated in a Government Regulation of the Republic of Indonesia No. 42 of 2007 concerning Franchising and several Ministerial Regulations. The application of this minimum clause is intended to protect prospective franchisees and franchisees alike.

\section{a. The Identity of the Franchisor}

The Franchisor's identity contains personal data of the franchisor, as well as personal data of shareholders, directors and commissioners. The provisions regarding the identity of the franchisor require the franchisor as well as the shareholder of the commissioners and directors to include photocopies of the identity cards or passports of these parties. Through the inclusion of this identity, prospective recipients will not only know the personal data of the franchisor, but also the personal data of the shareholders, commissioners and directors if the franchise is established in the form of a business entity. In addition, prospective franchisees can find out who is responsible for the franchise.

\section{b. The Legality of the Franchisor's Business}

Business legality in Government Regulation no. 42 of 2007 concerning franchise legality in the form of technical permits such as a Trading Business Permit (SIUP) if the franchise is carried out in the form of activities in the trade sector, a permanent tourism business permit which is a permit granted to a business engaged in the tourism sector, a permit for the establishment of an educational unit. which is a license granted to businesses 
running in the field of education, for example, tutoring businesses. If the franchisor comes from abroad, then it must have a business license which must be stated in the business license issued where the franchisor originates.

\section{c. History of Business Activities}

Through this provision, prospective franchise recipients can find out what activities the franchisor is doing so that the franchise can progress and develop and provide benefits for the franchisor. Prospective franchisees can also take the history of this business into consideration whether the franchise business is compatible with it or not.

\section{d. Franchisor's Organizational Structure}

On the explanation of Government Regulation No. 42 of 2007 concerning Franchising and Regulation of the Minister of Trade No. 53 of 2012 concerning Franchising, it is explained that this clause contains the organizational structure such as commissioners, who is the shareholder in the franchise and the Board of Directors up to the operational level who runs the franchise.

\section{e. Financial Reports for the Last 2 (Two) Years}

The obligation to attach these financial statements is regulated in Government Regulation No. 42 of 2007 regarding franchising. When seen in the Regulation of the Minister of Trade No. 53 of 2012 concerning Franchising in Appendix I explains that the financial statements contain financial statements or financial balance sheets of the franchising company for 2 (two) consecutive years counted back from the time of the franchise offering prospectus application and have been audited by a public accountant except for businesses micro and small.

\section{f. Number of Places of Business}

In the Regulation of the Minister of Trade No. 53 of 2012 Attachment I explains that what is meant by this place of business is an outlet or outlet for the franchise business in accordance with the Regency / City of domicile for the domestic franchisor, for the franchisor originating from abroad, the outlets or outlets available are listed in accordance with with the country of domicile of the franchisor.

\section{g. List of Franchisees}

The list of franchisees is clearer, as described in the Regulation of the Minister of Trade No. 53 of 2012 concerning Franchising Appendix I which mentions a list of franchise recipients containing a list of names and addresses of companies and / or individuals as franchisees, both domiciled in Indonesia and abroad. The disclosure of the franchisee list has the same purpose as the disclosure of the number of outlets or outlets of the franchisor, namely to see the success of the franchisor in running the franchise business.

\section{h. The Rights and Obligations of the Franchisor and Franchisee}

Government Regulation No. 42 of 2007 concerning franchising does not explain the rights and obligations of the franchisor or franchisee. A description of the rights and obligations of the franchisor and franchisee can be seen in Attachment I to Regulation of the Minister of Trade No. 53 of 2012 concerning Franchising which states that the rights and obligations of the franchisor and franchisee, such as: 
a. The franchisor is entitled to receive fees or royalties from the franchisee, and then the franchisor is obliged to provide continuous guidance to the franchisee;

b. The franchisee has the right to use the Intellectual Property Rights or business characteristics of the franchisor, and furthermore the franchisee is obliged to maintain the code of ethics / confidentiality of IPR or business characteristics provided by the franchisor.

\section{Results and Discussion}

\subsection{Comparison of the Content of the Prospectus Regulated in Indonesia, the United States and Australia}

In regulating the clauses that must exist in a prospectus document, each country has different provisions. In the United States, regulations regarding prospectus documents are regulated in the FTC Rule. The FTC Rule regulates what matters must be included in the franchise prospectus document. Just like in Indonesia, the FTC Rule also requires franchisors to provide their bid documents to franchisees.

In Australia, regulations regarding prospectus documents are regulated in The Franchise Code. The Franchise Code requires franchisees and potential franchisees to receive a copy of the disclosure document from the franchisor. In the United States, based on the provisions set out in the FTC Rule, the time limit is 14 (fourteen) days prior to the signing of the contract, in Australia, based on the provisions set out in The Franchising Code, the prospectus document is provided within the same period as regulated in America. Union, namely 14 (fourteen) days before the signing of the franchise agreement.

The provisions regarding the content of the clauses that must be included in the prospectus document vary from country to country. The following are differences regarding the matters that are regulated in the preparation of prospectus documents in the United States, Australia and Indonesia:

\section{a. The Identity of the Franchisor}

The identity of the franchisor contains information about the franchisor. in Indonesia as previously explained based on Article 7 of Government Regulation no. 42 of 2007 concerning franchising explains that the information listed contains a photocopy of the Identity Card or Passport of the franchisor if it is an individual and a photocopy of the Identity Card or Passport of the shareholders, commissioners and directors if it is a business entity.

In the United States, based on the FTC Rule in clause 1, it is stipulated that the identity that must be disclosed contains the full identity of the franchisor, sub franchisor, main franchisor, franchisor involved, the former franchisor. Each party must include the name, address, and clear information of the parties.

In Australia itself, disclosure regarding the identity of the franchisor can be seen in The Franchising Code in Appendix 1 regarding prospectus documents for franchisees and prospective franchisees, that what must be included in the franchisor's identity is the name, address and business address and registered telephone number as well as ABN, ACN or ARBN from the franchisor.

\section{b. Legality of the Franchise Business}

Regarding the legality of a franchise, Indonesia regulates that every business must have a license in accordance with the type of business being run. Unlike in Indonesia, the provisions regarding business legality that must be included in the prospectus document 
are not clearly regulated in the United States and Australia. It's just that if we look at The Franchising Code, it requires every company in Australia to have ABN, ACN, and ARBN in running every business. By having these three numbers, we can know that the business run by the franchisor is a legal company and has been registered with the Australian Securities and Investments Commission (ASIC).

\section{c. Business Experience}

Indonesian regulations do not regulate the inclusion of the franchisor's business experience. It's just that the business experience of this franchisor can be seen in the history of franchising that we will follow. Regarding the business experience of the franchisor in Indonesia in the history of franchising, it is usually only done briefly.

In the United States, the business experience regulation stipulates that the business experience that must be disclosed is the business experience of each party, including directors and chief officers in the last 5 (five) years. Business experience that is longer than 5 (five) years is acceptable, as long as the business experience of these parties matches the franchise business they are currently running.

In this clause Australia stipulates that every officer of the franchisor must have relevant experience for the last 10 (ten) years including experience in operating a business that is substantially the same as the franchise business and offering another franchise which is substantially the same as the franchise being run.

\section{d. Litigation}

Litigation is a clause that contains the disclosure of lawsuits that have been or are being experienced by the franchisor. For this clause, Indonesia does not regulate the obligation to disclose legal claims that have been experienced by the franchisor or the parties listed in the organizational structure that exists in the business.

The United States asserts in Item 3 that any party involved with the franchisor such as the predecessor, the parent franchisor, and the affiliates must disclose any legal claims involving him. The franchisor is also required to disclose litigation involving him as well as the parties involved with the franchisor, even if the action is in a foreign court or arbitration forum.

In Australia the provisions for disclosing litigation in The Franchising Code regarding litigation state that the obligation to disclose details of the current process by a public, criminal or civil entity relevant to franchising, against the franchisor, the director of the franchisor, the associate of the franchisor and the director the franchisor's association.

\section{e. Bankruptcy History}

This bankruptcy clause is intended to find out whether the franchise has experienced bankruptcy or not. Indonesian regulations do not stipulate an obligation to disclose a bankruptcy history in its prospectus documents. Similar to Indonesia, Australia also does not regulate the obligation for the franchisor to disclose his bankruptcy history in his prospectus documents.

America requires that bankruptcy records not only be disclosed by franchisors, affiliates and predecessors, but it is also obliged to disclose bankruptcy histories of parent franchises. Disclosures regarding the bankruptcy history of the parent franchise and its affiliates are disclosed by the franchisor in the 10 years prior to the issuance of the prospectus. In addition to disclosing the bankruptcy of the parent franchise and its affiliates, franchisors are also required to disclose the bankruptcy history of those who have management responsibility for the operation and sale of the franchise. 


\section{f. Initial Fees}

This initial fee is a clause that explains the initial costs that must be incurred by prospective franchisees if they want to join to use and sell the franchise for a profit. In Indonesia, the arrangements regarding initial costing are not explicitly regulated. The amount of this initial fee can be seen in the rights and obligations of the franchisor and franchisee, because the payment of this initial fee is one of the obligations of the franchisor to be able to use the franchisor's business.

In the United States what is meant by this initial fee is related to all fees and payments, or a commitment to pay for any services or goods received from the franchisor or its affiliates before the business is run, it will be determined whether the payment of this initial fee will be made in lump sum or done. by installments to the franchisor, and about how to get these initial costs back.

The initial fee payment in Australia is specified in Item 14 of The Franchising Code on Prepayment. The prepayment provisions state that the reasons for stating the initial payment, for what use of the initial financing and who will hold the money, as well as in what circumstances the initial fee can be returned by the franchisor to the franchisee and the details for what the initial fee is used.

\section{g. Other Fees}

Arrangements regarding the payment of other costs related to the use of the franchisor's business in Indonesian regulations are regulated in the rights and obligations clause of the franchisor and the franchisee. This provision becomes the right received by the franchisor from the franchisee for the permission given to use his franchise.

For the United States itself, provisions to pay other fees in the form of recurring fees include royalty payments, advertising costs, and transfer fees, including costs incurred in operating the outlet. The stipulation of other fees charged to the franchisee must also be stated regarding the types of fees charged, the amount determined by the franchisor to the franchisee, and the due date these costs must be paid by the franchisee to the franchisor. This other fee determination also includes all fees required by the franchise agreement and all costs required by the franchisor to start his business. Details regarding these other fees are made in the form of a table, making it easier for potential franchise recipients to understand what fees are charged to them and the amounts that must be paid by the franchisee.

In Australia, the stipulation of payment of other fees is regulated in Item 14 regarding Other Payment, which includes initial costs, establishment costs which contain details of the range of costs to start operating a franchise business, and other payments in the form of recurring payments. which must be paid to the franchisor or fellow franchisor, as well as fees that will be collected by the franchisor to be given to other parties relating to the operation of the franchise.

\section{h. Restrictions Regarding Products and Services}

Indonesia requires that anyone who wants and will run and develop a franchise business in Indonesia is obliged to use goods and / or services from Indonesian products and cooperate with small entrepreneurs who are around the franchise. This provision can be seen in Article 9 paragraph (1) and (2) Government Regulation no. 42 of 2007 regarding franchising. The restriction provisions are not only regulated in the Government Regulation on Franchising, but also in the Regulation of the Minister of Trade No. 68 of 2012 concerning Franchising for Modern Store Business Types Article 7, Regulation of the Minister of Trade No. 
In America the clause regarding restrictions on products and services regulates the purchases that are required to use as well as restrictions on the source of products and services, as well as the amount of income the franchisor receives from suppliers. This callusula also regulates what obligations the franchisor gives to buy or rent goods, services or supplies originating from a specified supplier which will be used to establish or operate the franchise business. The FTC Rule also sets limits on goods or services sold by franchisees. This restriction is provided for in Item 16 which states that it limits the sale of goods and services by the franchisee.

The provisions regarding restrictions regarding products and services in the country of Australia require that the franchisor specifies the supply of goods and / or services to the franchisor, maintains the level of obtaining a number of goods and services, the franchisor's obligation to supply goods and / or to the franchisor, restrictions imposed by the provider franchisees to obtain goods and services from other sources, the obligation of the franchisee to receive goods and services from the franchisor or those from fellow franchisors.

\section{i. Franchisee Obligations}

Indonesian regulations do not regulate in detail what obligations will be borne by the franchisee, it's just that in Government Regulation No. 42 of 2007 concerning franchising Article 7 requires the franchisor to determine the obligations for the franchisee in his prospectus document.

The clause regarding what obligations the franchisee has in the United States states that the disclosure of the obligations of the franchisee is disclosed in a table that refers to the franchise agreement or contract related to the franchise as well as documents where the obligations of the franchisor can easily be found by franchisee.

Whereas in Australia the obligations of the franchisee are not clearly regulated in The Franchising Code, but the obligations of these franchise recipients can be seen and concluded based on the clauses contained in The Franchising Code.

\section{j. Finance}

This clause requires the franchisor to disclose his financial statements at the time his prospectus documents are submitted to the prospective franchisee. Indonesia requires franchisors to include their balance sheets for 2 (two) consecutive years since the prospectus document has been audited by a public accountant.

The United States regulates the obligation for franchisors to disclose copies of financial statements for the last three fiscal years that have been previously audited with generally accepted accounting principles to reveal how their economy has developed over the three fiscal years.

For Australia itself, it is required to include their financial disclosure requirements at the end of the last financial year, and requires the franchisor to disclose the financial statements of the last two years of the Corporationa Act 2001 or its foreign equivalent that apply to the franchisor and those prepared by the provider franchise.

\section{h. Franchisor Assistance, Advertising, Computer Operating Systems and Training}

The provisions regarding this clause in Indonesia will be listed and explained in detail in the franchise agreement regarding what matters the franchisee will receive, the operating system and what training will be received. The types of obligations to get assistance from the franchisor can also be seen in the Regulation of the Minister of Trade No. 68 of 2012 concerning Franchising for Modern Store Business Types, Article 8 
regulates the obligations of the franchisor to provide guidance and training to the service system, Regulation of the Minister of Trade No. 07 of 2013 concerning Partnership Development in Franchising for Food and Beverage Service Business Types Article 8 which requires the franchisor to provide coaching and capital participation assistance in the form of training and instructions for managing the franchise business.

Provisions regarding the assistance to be provided in the United States by the franchisor to the franchisor are regulated in FTC Rule Item 11, which describes what kind of assistance the franchisor will receive from the franchisor. In the prospectus document issued by the franchisor, the franchisor will state the limitations regarding his obligation to provide assistance to the Franchisee which will be written in bold writing "Except as stated in this prospectus document the franchisor is not required to provide you with any assistance" .

In Australia, the provisions for disclosing the assistance to be provided by the franchisor in the form of marketing, the computer system used and the training to be received are not clearly stipulated in the stipulation of the clause that must be in the prospectus document.

\section{h. Territory}

In Indonesia, the determination of the boundaries of the area to be used by the franchisee in the prospectus document is not clear, right, but the boundaries of this area will be determined at the time of awarding the contract to carry out the cooperation to develop the franchise business.

The United States emphasizes that there are two important topics that must be included in the prospectus document regarding this area.

a. A condition in which the franchisor agrees to relocate the franchisee and establish an additional outlet for the franchisee.

b. Franchisors plan to operate the franchise system and compete to offer similar goods and services.

If the franchisor does not provide or provide an exclusive area for the franchisee, then the franchisor is obliged to include a warning in his prospectus document regarding this matter and the consequences that the franchisor will receive from not providing an exclusive area. The warning contains:

"You will not receive exclusive territory. You may face competition from other franchisees from our outlets, or from other distributors or competitive brands that are under our control. "

In Australia, this territorial designation is regulated in The Franchising Code Item 13 which states that the franchisor has a policy to select as many territories as possible to offer to potential franchisees as well as areas where the franchise will operate.

\section{i. Intellectual Property Rights}

In Indonesia, disclosure of intellectual property rights is made by the franchisor when submitting the franchise agreement. So there is no obligation for the franchisor to disclose his intellectual property rights at the time of granting the prospectus to prospective franchisees and franchisees. Regulations regarding intellectual property rights in Indonesia are specifically regulated in laws and regulations, which govern what must be done in order to protect their intellectual property rights. 
Minister of Trade Regulation No. 60 of 2013 concerning the Obligation to Use the Franchise Logo requires franchisors and franchisees to use the franchise logo which is the hallmark of the franchise, and regulates who is entitled to give and receive the use of this franchise logo. The giver can protect his intellectual property rights by registering IPR according to its type, such as registering a trademark or service mark in accordance with Law No. 20 of 20016 concerning Trademarks and Geographical Indications, to protect copyright is regulated in Law No. 28 of 2014 concerning Copyright, for Patents regulated in Law No. 13 of 2016 on Patents.

In America, the obligation to disclose intellectual property rights, patents, trademarks, copyrights and is also stipulated in two different items. Item 13 that deals with trademarks states that the franchisor is obliged to disclose the respective trademarks he owns, whether it is registered with the United States Patent and Trademark Office. If the trademark is not registered, the franchisor is obliged to provide notification that their trademark is not registered and the consequences that will be faced by the prospective franchisee.

Meanwhile, Australia regulates that it is an obligation for the franchisor to disclose what trademarks are used by the franchisor in order to easily identify any patents, designs or copyrights that are important to the franchise. The disclosure of IPR must also specify the rights and obligations of each franchisor related to the use of intellectual property.

\section{j. Outlet and List of Franchisees}

This disclosure obligation is also regulated in a minimum clause that must be included by the franchisor, and this obligation can be seen in Government Regulation No. 42 of 2007 concerning Franchising Article 7 which states that the franchisor's prospectus must include the number of places of business he owns, as well as a list of franchisees.

In addition to the Government Regulation on Franchising, the provisions which require disclosing the number of outlets can also be seen in the Regulation of the Minister of Trade No. 07 of 2013 concerning Partnership Development in Franchising for Food and Beverage Service Business Types Article 10 which requires the franchisor to report back on changes in the number of outlets it owns. The regulation of this outlet is also regulated in the Regulation of the Minister of Trade No. 68 of 2012 concerning Franchising for Modern Store Business Types, which regulates how this modern store develops its business by setting up outlets and regulates the size of outlets that this modern store must have.

Disclosure of the number of outlets and the information of the franchisee is required in the preparation of a prospectus document in the United States which states that it requires the franchisor to provide information on the number of outlets and companies that operate these outlets in a three year period. Franchisors are also required to disclose the contact information of their former franchisees.

Australia is not obliged to disclose information about the number of outlets or information from any of its franchisees. This can be seen from The Franchising Code which does not include provisions for disclosing such information.

\section{k. Renewal, Termination, Transfer and Dispute Resolution}

In Indonesia, this clause is not required to be included in the issuance of prospectus documents to franchisees. This clause has just appeared and will be discussed at the time of submission of the franchise agreement document. It is in this franchise agreement document that the franchisee will know how the agreement will be carried out if they want to renew, terminate, transfer and settle in the event of a dispute. 
Unlike in Indonesia, the United States and Australia have also arranged for renewal, termination, transfer and dispute resolution to be carried out, the prospective franchisee can know the provisions when the prospectus document is given by the franchisor to the franchisee. This clause in the United States is regulated in Item 17 of the FTC Rule. Item 17 of this FTC Rule requires the franchisor to include how this franchise agreement will be renewed, terminated, transferred and how the dispute resolution will be carried out.

Australia regulates this clause in several Items. Item 18 provides for the arrangements that will be made at the end of the franchise agreement. This item applies whether the franchisor can extend the term of the franchise agreement or enter into a new franchise contract. What if a franchisee has no choice in renewing his franchise agreement. Item 19 regulates before the franchise transfer occurs, whether the franchisor will amend or change the franchise agreement.

\subsection{Can the Regulations on the Content of the Prospectus in Indonesia Provide} Protection to Franchisees Compared to the United States and Australia

Regarding the determination of the prospectus content, the role of legal protection is very much needed. As previously explained, the Prospectus is used as a marketing medium for franchisors to offer their franchises. In Indonesia, to protect parties involved in franchising, the government makes regulations that are used as guidelines and supervises every franchisor to make his prospectus documents.

In connection with running a franchise activity, the prospectus document is used as the initial legal protection for the franchisee, because it is through this prospectus that the franchisee wants to participate or not to run the franchise business owned by the franchisor based on the information contained in the prospectus document. As previously explained, in making a prospectus Indonesia requires 8 (eight) minimum clauses that must exist. Based on the comparison of the contents of the prospectus that has been compared before, it can be said that there are several things that are not regulated in the clause of the prospectus preparation in Indonesia but are regulated in the United States and Australia.

When we compare it with other countries, the regulations in Indonesia governing the terms of a prospectus are considered simpler and less open about the advantages and disadvantages of the franchise. This lack of openness about the franchise business is often more detrimental to franchisees, which results in biased positions of the franchisor and franchisor.

\section{Conclusion}

From the comparisons made, it can be seen that there are several provisions regarding clauses in the issuance of prospectuses between the United States, Australia and Indonesia, but the provisions in each of these clauses differ from one another. There are also some differences in the application of prospectus clauses, namely that there are several regulations that must be explicitly and clearly stated in the franchise prospectus in the United States and Australia, but in Indonesia these clauses are not regulated.

From the comparisons that have been made, it can be seen that the minimum clause that is regulated in Indonesia in the issuance of a prospectus is very simple compared to the United States and Australia. Not only the contents of the clause, but the provisions of each clause are deemed unclear and firm. From this comparison, we can see that the regulations regarding the establishment of clauses in Indonesia are still not able to protect franchisees in Indonesia. Especially with the advancing times, the provisions of the prospectus minimum clause are no longer able to follow and protect the franchisees. 


\section{References}

Acintya Paramita. (2011). "Perlindungan Hukum Terhadap Para Pihak Dalam Perjanjian Waralaba Antara Pihak PT IMPERIUM HAPPY PUPPY Dengan Pihak X" dalam

Tesis, Fakultas Hukum Program Pascasarjana Universitas Indonesia, Jakarta.

Adrian Sutedi. (2008). Hukum Waralaba, Ghalia Indonesia, Jakarta.

Andrew P. (2006). Loewinger and Michael K. Lindsey, International Franchise Sales Law, ABA Publishing.

Andito Aodijulistio. (2011). Perlindungan Hkum Calon Penerima Waralaba Berdasarkan

Prospektus Penawaran Waralaba, Tesis Hukum Universitas Katolik Parahyangan,

Bandung.

Anonymous, Konsep Perlindungan Hukum

Anonymous, Sejarah Pengaturan Tentang Waralaba Indonesia, repository.usu.ac.id

Gunawan Widjaja. (2002). Lisensi atau Waralaba Suatu Panduan Praktis, Jakarta, PT Raja Grafindo Persada.

Calvin Smith Houtsman Sitinjak, Pengaturan Prospektus Penawaran Waralaba Dalam Perjanjian Waralaba, Program Kekhususan Hukum Bisnis, Fakultas Hukum, Universitas Udayana.

Federal Trade Comission Rule (FTC Rule). The Franchising Code.

H.U.Adil,SS. (2016). Dasar-Dasar Hukum Bisnis, Edisi Kedua, Mitra Wacana Media, Jakarta.

http://konsultanwaralaba.com dalam artikel Waralaba Waralaba Cara Mudah Membuat Prospektus Waralaba.

https://www.franchiselawsolutions.com, Franchising State Specific Law.

https://www.ftc.gov, Frachises, Business Opportunities, and Investments Rule Summary.

https://iclg.com, practice-areas franchise-laws and regulations Australia

John Sier and Philip Colman, IFA Australian Franchise, What is the legal definition of a franchise?

Karyono, O and Agustina, K. (2019). Determining the Priority Strategy in the Implementation of E-Government Through Swot Analysis Model. Budapest International Research and Critics Institute-Journal (BIRCI-Journal).P. 66-74

Michel H.Seid, and Joyce Mazero. (2017). Franchise Management For Dummies, John Wiley \& Sons Inc, Hoboken, New Jersey.

Moch. Basarah \& M. Faiz Mufidin. (2008). Bisnis Waralaba dan Aspek-Aspek Hukumnya, PT. Citra Aditya Bakti, Bandung.

Pan Lindawaty Suherman Sewu. (2009). Pranata Hukum Waralaba di Uni Eropa dan Amerika dalam Upaya Memberikan Perlindungan Hukum Bagi Para Pihak dalam Perjanjian, Jurnal Dialogia Luridicia, Vol 1.

Peraturan Pemerintah No. 42 tahun 2007 tentang Waralaba.

Peraturan Menteri Perdagangan No. 53 tahun 2012 tentang Penyelenggaraan Waralaba.

Peraturan Menteri Perdagangan No. 68 tahun 2012 tentang Waralaba untuk Jenis Usaha Toko /ran Menteri Perdagangan No. 60 tahun 2013 tentang Kewajiban Penggunaan Logo Waralaba.

P. Lindawaty S. Sewu. (2004). Franchise Pola Bisnis Spektakuler Dalam Perspektif Hukum \& Ekonomi, CV.Utomo,Bandung.

Richard Greenstein \& Philip F. Zeidman, Franchise In United States, IFA.

Rooseno Harjowidigdo, Munir Fuadi. (2002). Pengantar Hukum Bisnis, Citra Aditya Bakti, Bandung. 